\title{
Race, Class and Income Inequality in Brazil: A Social Trajectory Analysis
}

\author{
André Salata \\ Pontifícia Universidade Católica do Rio Grande do Sul (PUCRS), Porto Alegre, RS, Brasil. \\ E-mail: andresalata@gmail.com ORCID: http://orcid.org/0000-0002-7236-4917
}

\section{INTRODUCTION}

In a recent episode in Brazil, after a famous black actress made a speech in which she reported being a constant victim of discrimination, the state of Rio de Janeiro's then education secretary made the following statement: "Any racial idiocy thrives. The latest one is a beautiful, sweet-smelling actress saying that people change sidewalks when they see her son, who is also probably beautiful and sweet-smelling" (O Globo, 2017). His reaction directly refers to a basic idea concerning Brazilians' self-image, which has prospered for a long time and contributed to forming our national identity in the middle of the last century - but which many scholars had believed to be in the process of being overcome - according to which there is no racial but only class inequality in Brazil (Telles, 2003; Guimarães, 1999).

The relationship and weight of race and class as different principles of stratification (Treiman, 1970; Parsons, 1940) has been a subject of reflection in the field of sociology for many decades now (Massey, 1990; Wilson, 1978; Wright, 1978; Meer and Nayak, 2015). In Brazil, very sound evidence accumulated over the last decades, especially regarding income inequality (Silva, 2000, 1988, 1980, 1978; Hasenbalg, 1979; Figueiredo Santos, 2005; Osorio, 2009; Arias, Yamada and Tejerina,

\footnotetext{
* This study is the product of a research project funded by the Brazilian National Council for Scientific and Technological Development (Conselho Nacional de Desenvolvimento Científico e Tecnológico - CNPq). This paper was produced within the framework of the Social Debt Observatory of Catholic Universities in Latin America (Red de Observatorios de la Deuda Social en Universidades Católicas de América Latina - RedODSAL).

Thanks to CNPq for the funding provided through the research productivity scholarship. Thanks also to the referees of DADOS, whose criticism and suggestions allowed me to improve the analysis and text presented here.
}

DADOS, Rio de Janeiro, vol.63(3): e20190063, 2020.

https://doi.org/10.1590/dados.2020.63.3.213 
2004; Arcand and D'Hombres, 2004), strongly confirms the net effect of race on life-chances. It would thus be very odd nowadays to find a social researcher who agrees with the state secretary's statement. Nonetheless, there is yet much to know about the process of stratification which results in racial income inequality and the relative importance of race and class within it. This article gathers and analyses new and more detailed evidence which contributes to the debate on this topic.

After 130 years of the abolition of slavery in Brazil, which formally allowed the entire black population to become part of a modern and developing labour market, racial imbalance is still enormous in the country; to the point that, in 2015, the average labour income of blacks was approximately $40 \%$ lower than that of whites. The main objective of this analysis, then, is to investigate the process of stratification which results in racial income inequality, from class of origin ${ }^{1}$ to the setting of wages definition. Using a structural equations model based on newly developed routines we were able to more precisely measure and understand the intensity and paths through which race, as well as social origin, influences income, identifying their direct and indirect effects. The data we use, from the National Household Sample Survey (Pesquisa Nacional por Amostra de Domicílios - PNAD), collected by the Brazilian Institute of Geography and Statistics (Instituto Brasileiro de Geografia e Estatística - IBGE) in 2014, is representative of the Brazilian population.

In the following section we present and debte the theoretical perspectives which underlie the hypotheses of this work. In the subsequent section, we discuss the methodology along with the data and data organization. The third segment exposes and analyses the results in relation to the previously reviewed debate. Finally, in the conclusion, we return to the main issues addressed, relating them to the results, and we indicate the contributions and limitations of the article in relation to the current discussion on this topic in Brazil.

\section{RACE AND CLASS AS EXPLANATORY FACTORS OF INEQUALITY}

Brazil bears the sad mark of having been the last Western country of Christian tradition to ban slavery. Between the sixteenth and nineteenth centuries, more than four million blacks were brought from Africa as slaves, so that in 1822, the year of Brazil's independence from Portugal, approximately one third of the Brazilian population was still in that situation (Carvalho, 2001). 
It is estimated that in the last quarter of the XIX century - near the date of abolition, passed in 1888 and after the adoption of several measures aimed at reducing the number of slaves throughout the nineteenth century -, slaves represented less than $15 \%$ of the population, since more than $70 \%$ of blacks are believed to be free/freed at that time. However, to the free/freed black population were not given opportunities for educational qualification or land ownership; as a result, they were concentrated in the bottom of the occupational structure - a similar situation to the one experienced by most subsequently free/ freed slaves (Hasenbalg, 1979).

Nowadays, more than 130 years after the abolition, ca. 55\% of the Brazilian population is composed of blacks ${ }^{2}$ and, as Figure 1 demonstrates, inequalities between blacks and whites are high and persistent.

Figure 1

Mean income from work* for blacks and whites

(Brazil, 1995-2015)**

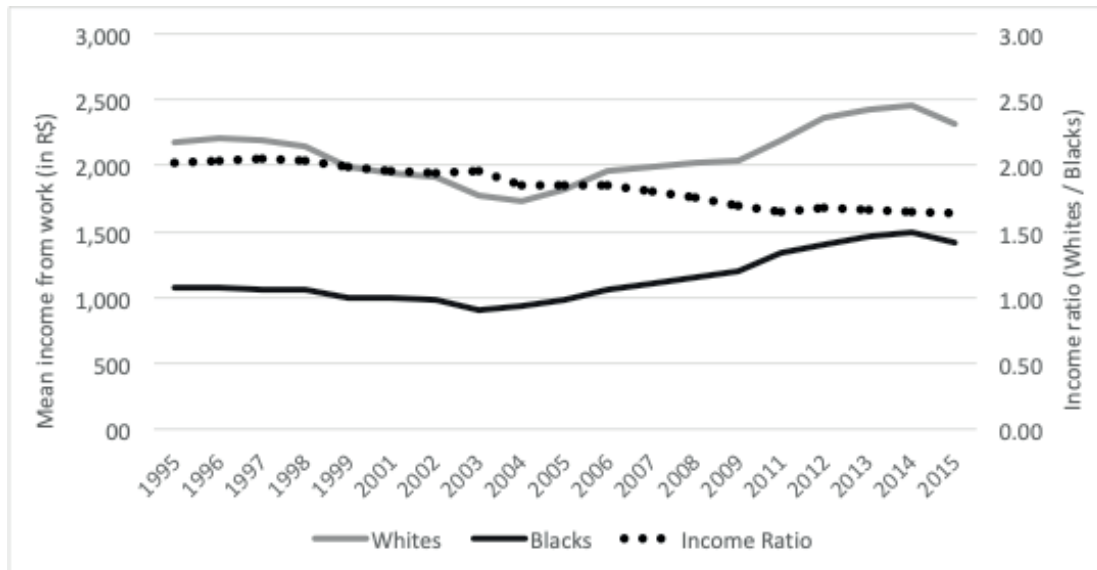

Source: IBGE (2014).

*Constant prices, at 2015 values according to Brazil's National Consumer Price Index (Índice Nacional de Preços ao Consumidor - INPC).

**Individuals aged $20-64$.

As shown by Figure 1, which covers the last two decades, the mean income for blacks is significantly lower than that of whites, so that blacks earned on average $42 \%$ less than whites in 2015 . Nevertheless, the dotted line also shows that the advantage of whites has declined - from a 2.0 ratio in 1999 to 1.64 in 2015 -, which reinforces the convenience of updating this kind of investigation. 
Possible causes for such stark inequality between whites and blacks have been debated for decades. We can distinguish different sociological theories formulated to explain this phenomenon in accordance with the weight they place on social background and its corresponding factors (e.g. education) or on racial discrimination itself. This debate is not restricted to the Brazilian case, and it dates back to different readings about the relationship between distinct principles of stratification and the economic-industrial development (Kerr et al., 1960; Blumer, 1965).

Wilson $(1978,1987)$, for instance, argued that nowadays in the United States racial hierarchy plays a mere secondary role in the process of stratification, as a significant historical cause of differences between whites and blacks in terms of socioeconomic origin, partly explaining why blacks compete, under unfavourable conditions, for opportunities in the modern labour market. Class condition, in its turn, would act directly and indirectly - through its effects on education, socio-spatial segmentation and the conformation of social networks - as the main explanation of inequalities between whites and blacks.

Other approaches, however, argued that racial hierarchy, as a stratifying principle, is still very relevant in contemporary society (Feagin, 1991). Racial categories - based on phenotypic characteristics such as skin colour, hair type, lip thickness as well as ancestry - serve to rank individuals, assigning them more or less prestige (Rollock, 2014) and thereby shaping their treatment by others (Bertrand and Mullainathan, 2004), their self-image, expectations, and self-confidence (Steele, 2003). Thus, racial hierarchy would function as an important mechanism conditioning life chances for different categories (Massey, 2007; Boliver, 2016) ${ }^{3}$.

The key point of this debate, therefore, has been the extent to which the observed inequalities between blacks and whites should be attributed to different starting points - which, in turn, would affect school performance and other characteristics achieved by different individuals (class effect) - or to the effect of racial hierarchy itself, usually understood as discrimination, which could occur at different moments in the life cycle. 


\section{THE DEBATE ABOUT RACIAL INEQUALITIES IN BRAZIL}

The Brazilian case provides an interesting context with regard to this subject (Bailey, 2004, 2008; Telles and Bailey, 2013; Telles, 2003), so that many authors have even denied the presence of race stratification in the country, taking it mostly as an epiphenomenon of class inequality (Pierson, 1967). In this reading - which had a great influence on the formation of the Brazilian national identity in the first half of the twentieth century (Freyre, 1986), and which still resounds rather significantly outside specialized circles -, the racial mixture characteristic of Brazil, the presence of blacks and mestizos occupying high positions, and the identification of intermediate racial categories (e.g. "mulattos") were evidences of a softened presence of racial discrimination in the country (Wagley, 1952). According to this perspective, social origin (classes) and not racial hierarchy - should explain inequalities between whites and blacks, which would be overcome as the country distanced itself from its history of slavery.

In a distinct approach, a famous study by Fernandes (1965) was one of the first major works to recognize the role still played by racial discrimination in the life chances of blacks in Brazil. However, he understood it as a phenomenon which was being overcome - a legacy of the slave-owning past which would be supplanted by a competitive social order which was then emerging in the country. Once slavery had been banished, the social function of racism - legitimizing white domination - would disappear. Racial discrimination, thus, would be an atavism, a legacy of slave society that would gradually fade away with the process of modernization.

Pinto (1953), in turn, stated that racial discrimination tended to increase. As society became more open and blacks climbed to higher social positions, racial discrimination would emerge as a mechanism for blocking the greater competition, to the detriment of blacks. Racism would cease to be the justification of the slave order in order to become a defence mechanism of privileged groups against the rise of blacks (Cardoso, 1977; Hasenbalg, 1979). Therefore, it was bound to rise rather than fall.

In recent decades, more empirical research on this topic has shown that racial discrimination ${ }^{4}$ is in fact such a relevant factor for explaining income inequality in Brazil that blacks have a lower income than whites not only due to characteristics like place of residence and edu- 
cation, but also due to discrimination itself. Countless studies conducted in recent years - based on representative samples of the Brazilian population - have concluded that there is a significant and direct effect of race on income, regardless of variables such as education and experience (Silva, 2000, 1988, 1980, 1978; Hasenbalg, 1979; Figueiredo Santos, 2005; Osorio, 2009; Arias, Yamada and Tejerina, 2004; Arcand and D'Hombres, 2004).

Some of those studies have also shown that, although sheer racial discrimination is a relevant factor for explaining wage inequalities between whites and blacks, much of it could be attributed to other factors, such as geographic and occupational composition and, in particular, to the level of education achieved by individuals from different racial categories. A smaller number of studies - such as Osorio's (2009), Silva's $(1988,2000)$ and Arias et al. (2004) - have directly inserted social origin into analyses, along with education and race ${ }^{5}$.

Osorio's (2009) research was developed, among other things, by regressing income on a large group of variables which included race; and, in a subsequent step, by regressing schooling on several variables, including race and social origin. His chief result indicated that, although race had a significant direct effect on income from work, the main explanation for income inequalities in favour of whites was social origin (household income and parent's schooling) and its indirect effects on income through education. Social origin had a profound effect on schooling, while the latter was the main variable explaining income variation in Brazil. In addition to the effects of class, racial hierarchy itself contributed to the explanation of inequalities, adding more disadvantages for blacks.

Thus, Osorio (2009) was able to demonstrate how racial inequalities can be explained by cycles of disadvantages in which the effects of class on income through education played the central role, being accompanied by the effects of race itself. However, as Osorio (2009) did not work with a single model that included race, education, and social origin altogether, it was not feasible to precisely calculate the magnitude of indirect effects - such as the effect of race on income through education. This would have allowed him to more formally test his hypothesis concerning the role of race in comparison with social origin in the process of setting income differentials. 
Silva's (2000) paper, in its turn, updated his previous interpretations of racial inequalities within the Brazilian labour market (Silva, 1980, 1985). Making use of national data collected in 1996, he conducted a decomposition analysis of income differences between whites and blacks - as he had done previously. The analysis included variables such as schooling, experience, geographical region, father's occupational status and father's years of education. As a result, he discovered that

although most of the differences in average income between the groups can be attributed to differences in average levels in the predictor variables [...] discrimination still appears to determine a sizeable portion of income differences, (Silva, 2000, p. 26).

even if we keep constant variables such as education and social origin.

Arias, Yamada and Tejerina (2004), by making use of quantile Mincer earnings regressions, goes beyond the more usual decomposition technique of average earning gaps. The research aimed to investigate the role of race, family background and education in Brazilian racial inequality. Its main results showed that the advantage of whites in the accumulation of human capital - including parents' schooling -, as well as in the return to their educational investment, was responsible for a major portion of racial inequalities. Thus, as done by Osorio (2009) and Silva (2000), despite recognizing the role of race itself, they ranked family background and education as the main explanations for racial income inequality.

However, if, on the one hand, techniques applied by Silva (2000) and Arias, Yamada and Tejerina (2004) enabled the decomposition of racial income inequalities into explained components - attributed to predictors - and non-explained components - attributed to discrimination, on the other hand these techniques did not allow them to verify and measure indirect effects of race and social origin on income, which could be as important as direct ones. It means that their analyses were blind to the role of race and social origin in previous stages - including educational differentials and occupational allocation - of the process leading to income inequalities.

In an article published in 1988, however, Silva applied structural equation models to national data collected in 1976. This way, he was able to assess the weight of race and family background on the status attainment 
process as a whole, and to verify that race itself, even when controlling for origin-related variables, affected educational attainment, occupational allocation and income. Silva (1988) concluded, after considering direct and indirect effects, that racial discrimination was responsible for the major portion of income inequalities between blacks and whites. Therefore, the results he achieved indicate that the weight we can attribute to race or family background when explaining income inequalities between whites and blacks might change substantially if we also consider indirect effects.

Nevertheless, data analysed by Silva (1988) were collected more than four decades ago, and back then he was able to make use of very few control variables - a dummy indicating rural and urban places, and another one separating developed and underdeveloped geographical regions -, which might have led to overestimating the weight of race. Besides, as he ran the model for whites and blacks separately, the distinction between direct and indirect effects, as well as the identification of the main paths through which race and social origin affects income, was not so straightforward ${ }^{6}$. Therefore, there are several reasons which could justify the application of a similar - but more advanced - model to recently collected data.

Thus, although nowadays we find a high degree of consensus regarding the effect of race on income inequality regardless of social background, there is still an important debate on its precise total weight - in comparison with social origin - within the process that leads to income differentials, and much to know about the paths through which both - race and social background - affect individual economic outcomes. Besides, in 2014, and after almost two decades since 1996, IBGE collected once again information about interviewees' social origin, allowing us to update this kind of investigation after a period when racial inequality has decreased (Figure 1).

\section{HYPOTHESES, DATA AND METHODS}

Based on the discussion presented in the previous section, we propose the following hypotheses to be tested:

H1: Race has direct and indirect effects on income which do not depend on social origin;

H2: The total effect of social origin on income is greater than the total effect of race, and occurs mainly indirectly, through schooling;

H3: Social origin disparities explain most income inequalities between whites and blacks. 
The first hypothesis derives from approaches which attribute important role to race as a stratifying principle, which might reduce the income of blacks directly and indirectly - through education and occupational allocation - regardless of their social origin. The second hypothesis, however, states that, despite race having an independent effect on income, the effects of social origin are more relevant, especially in light of its impact on schooling. Together, therefore, the hypotheses recognize class and race as two distinct but active principles of the stratification process, both of which operate to the detriment of the black population, affecting their income directly and indirectly.

The third hypothesis, in its turn, affirms that a major proportion of mean income differences between whites and blacks can be attributed to the class of origin - that is, to their unequal starting points -, despite the role played by race itself. This way, it follows recent research results which, despite recognizing the net effects of race, rank class as the main factor behind whites' advantages. Thus, it directly contrasts divergent readings about the importance of class and race for setting income differentials between whites and blacks, reflecting the distinct approaches discussed in the previous section.

\section{Data and techniques}

We use data from PNAD, collected by IBGE for 2014. The PNAD is a yearly sample survey - except for years when the Brazilian census is taken - and its sampling is done probabilistically, so that the resulting sample can be considered representative of the Brazilian population ${ }^{7}$. In 2014, a complementary questionnaire on social mobility was administered, which enabled the collection of information on respondents' social origin, along with all variables routinely provided by PNAD's microdata (e.g. gender, colour, age, education, income). In each household it was selected a person of at least 16 years of age to respond to the complementary module, which was replied to by a sub-sample of 57,890 observations out of the 2014 larger sample $(362,627$ cases).

For the analysis, we made use of a recursive structural equation model, which has been widely used in studies on inequality and social stratification since the seminal work carried out by Blau and Duncan (1967). We only included individuals between 20 and 64 years of age, and, as we were interested in the effect of race on income from work, we had 
to reduce our sample to individuals who were employed in that period. Also, individuals employed but without income were discarded from our analysis.

Upon executing the models, we made use of sample weights without, however, expanding the sample, thus allowing us to test hypotheses with the actual number of cases. We also used robust standard errors for all coefficients, which made results more reliable. The estimation method was maximum likelihood with missing data (MLMV), which does not use the listwise deletion option and thus enables all the information contained in the database to be worked with. All estimates were performed using Stata/IC v.15 software, through structural equation modelling (SEM) routines.

Table 1 shows the list and description of variables used, while Figure 2 - inserted in the following pages - shows the position of these variables within the model ${ }^{8}$.

Table 1

Variables

\begin{tabular}{|c|c|c|c|c|c|}
\hline Name & Nature & Type & $\begin{array}{c}\text { Blocks } \\
\text { (control } \\
\text { variable) }\end{array}$ & Description & Categories \\
\hline \multicolumn{6}{|c|}{ Endogenous variables } \\
\hline Income & Observed & Interval & --- & $\begin{array}{l}\text { Natural logarithm } \\
\text { of the gross monthly } \\
\text { income from the } \\
\text { main job divided by } \\
\text { monthly workload } \\
\text { (in hours) }\end{array}$ & --- \\
\hline Occupation & Observed & Interval & --- & $\begin{array}{l}\text { Status (ISEI) of the } \\
\text { occupation for the } \\
\text { main job }\end{array}$ & --- \\
\hline Education & Observed & Interval & --- & $\begin{array}{c}\text { Years of study } \\
\text { completed }\end{array}$ & --- \\
\hline \multicolumn{6}{|c|}{ Exogenous variables of interest } \\
\hline Blacks & Observed & Dummy & --- & $\begin{array}{l}\text { Racial self-identifi- } \\
\text { cation }\end{array}$ & $0=$ whites $/ 1=$ blacks \\
\hline Social origin & Latent & Interval & --- & $\begin{array}{l}\text { Socio-economic level of } \\
\text { the family of origin }\end{array}$ & --- \\
\hline
\end{tabular}


Table 1

Variables (cont.)

\begin{tabular}{|c|c|c|c|c|c|}
\hline Name & Nature & Type & $\begin{array}{l}\text { Blocks } \\
\text { (control } \\
\text { variable) }\end{array}$ & Description & Categories \\
\hline \multicolumn{6}{|c|}{ Exogenous indicator variables (of "Social origin") } \\
\hline $\begin{array}{l}\text { Cultural } \\
\text { resources }\end{array}$ & Observed & Interval & --- & $\begin{array}{l}\text { Average education of } \\
\text { the occupation of the } \\
\text { father or mother (the } \\
\text { highest value), when } \\
\text { the interviewee was } 15 \\
\text { years old }\end{array}$ & --- \\
\hline $\begin{array}{l}\text { Economic } \\
\text { resources }\end{array}$ & Observed & Interval & --- & $\begin{array}{l}\text { Median income of } \\
\text { the occupation of the } \\
\text { father or mother (the } \\
\text { highest value), when } \\
\text { the interviewee was } 15 \\
\text { years old }\end{array}$ & --- \\
\hline \multicolumn{6}{|c|}{ Exogenous control variables } \\
\hline Region of origin & Observed & Dummies & 1 & $\begin{array}{l}\text { Geographic region } \\
\text { of residence when } 15 \\
\text { years old }\end{array}$ & $\begin{array}{l}\text { 1=North / } \\
\text { 2=Northeast / } \\
3=\text { Southeast or } \\
\text { foreign country } \\
\text { (reference) / 4=South } \\
\text { / } 5=\text { Center-west }\end{array}$ \\
\hline Place of origin & Observed & Dummies & 1 & $\begin{array}{l}\text { Place of residence } \\
\text { when } 15 \text { years old }\end{array}$ & $\begin{array}{l}0=\text { Rural (reference) / } \\
1=\text { Urban / 2=Urban- } \\
\text { Capital }\end{array}$ \\
\hline Family of origin & Observed & Dummy & 1 & $\begin{array}{l}\text { Indicator of single- } \\
\text { parent family, when } 15 \\
\text { years old }\end{array}$ & $\begin{array}{l}0=\text { Non single-parent } \\
/ 1=\text { Single-parent }\end{array}$ \\
\hline Women & Observed & Dummy & $1,2,3$ & Indicator of women & $0=$ Men $/ 1=$ women \\
\hline Age & Observed & Interval & $1,2,3$ & Age, in years & -- \\
\hline Current region & Observed & Dummies & 2,3 & $\begin{array}{l}\text { Geographic region } \\
\text { currently living }\end{array}$ & $\begin{array}{l}\text { 1=North / } \\
\text { 2=Northeast } \\
\text { / 3=Southeast } \\
\text { (reference) / 4=South } \\
\text { / 5=Center-west }\end{array}$ \\
\hline Current location & Observed & Dummies & 2,3 & $\begin{array}{l}\text { Location where cur- } \\
\text { rently living }\end{array}$ & $\begin{array}{l}0=\text { Rural (reference) / } \\
1=\text { Urban / 2=Urban- } \\
\text { Metropolitan }\end{array}$ \\
\hline
\end{tabular}


Table 1

Variables (cont.)

\begin{tabular}{|c|c|c|c|c|c|}
\hline Name & Nature & Type & $\begin{array}{c}\text { Blocks } \\
\text { (control } \\
\text { variable) }\end{array}$ & Description & Categories \\
\hline Migration & Observed & Dummy & 2,3 & $\begin{array}{l}\text { Indicator of person } \\
\text { who moved interstate } \\
\text { after } 15 \text { years of age }\end{array}$ & $\begin{array}{l}0=\text { Non-migrant } / \\
1=\text { Migrant }\end{array}$ \\
\hline Age & Observed & Interval & 3 & $\begin{array}{l}\text { Age, in years, } \\
\text { squared }\end{array}$ & --- \\
\hline Years & Observed & Interval & 3 & $\begin{array}{l}\text { Years of experience in } \\
\text { current job }\end{array}$ & --- \\
\hline
\end{tabular}

\section{Endogenous variables}

Our main endogenous variable is monthly gross income from main job divided by monthly workload - in Brazilian Reais, at 2014 prices. When interviewee had more than one job, the main job was the one in which he had stayed longest in the year of the survey. Since the distribution of this variable and the format of its relationship with some of the main independent variables are known to be asymmetric, we use its natural logarithm.

The second endogenous variable - this time a mediating one - concerns the socioeconomic status of the occupation, which is measured by the International Socioeconomic Index (ISEI), one of the best-known measures in studies on social stratification. ISEI was developed to measure the attributes of occupations that convert education into income, being positively correlated to both (Ganzeboom, De Graff and Treiman, 1992). The higher the ISEI value of an occupation, the higher its socio-economic level.

The third endogenous variable - also a mediating one - is individuals' education, measured in years of study completed. Classification according to years of study is obtained from the grade and level the person was at - or had attended -, with the last grade concluded being considered, so that each grade successfully completed corresponds to one year of study. The measure assumes the value 0 for individuals who have not completed at least one year of study, and it goes up to 15 for individuals who have completed 15 or more years of study, which usually means having completed at least the undergraduate level of tertiary education. 


\section{Exogenous variables}

Among exogenous variables, of particular note is the one that distinguishes blacks and whites based on their self-identification. This information is obtained by means of a stimulated question, in which respondents can identify themselves - and, in many cases, some of their relatives, if they are absent at the moment - with one of the following categories: white, black, yellow (a category which comprehends those who identify as Japanese, Chinese or Korean in origin), brown (including the terms that indicate an intermediate layer between whites and blacks, and/or mestizos; for example, mulattoes, caboclos, cafuzos, and mamelucos), or indigenous (considers persons who declare themselves to be indigenous or natives). As residual categories, which corresponded to less than $1 \%$ of the population, those classified as yellow or indigenous were not considered in the analysis ${ }^{9}$.

Despite the known complexity of the Brazilian racial classification system (Monk Jr., 2016; Bailey, Loveman and Muniz 2013), many studies have already shown that, as far as income is concerned, there are no substantial differences between black and brown-skinned individuals, and the main gap is found between whites and non-whites (Silva, 1980; Osorio, 2009). For this reason, as usual among researchers of social stratification in Brazil, we will make use of a binary variable that unites both categories - black and brown - into one: blacks. This, therefore, will be the variable responsible for capturing the effects of race.

To measure social origin, we use a latent variable ${ }^{10}$ which aims to indicate the socioeconomic level of the family of origin, based on information regarding parents' income and schooling. We run, therefore, a structural model with formative indicators and, to enable the identification of the model, the variance of the latent variable (Social Origin) was set to " 0 ", and the load of one of the indicator variables of the model (Economic Resources) was set to "1" (Acock, 2013).

Both indicators of social origin - economic and cultural resources - were measured through the main occupation of guardians (heads of household and partners) when interviewees were 15 years old. From 2014 data, we calculated median values of income and the mean value of completed years of schooling for each occupational category, subsequently assigning values to guardians in accordance with their occupation ${ }^{11}$. The economic and cultural resources of the family of origin are given by the highest average income and level of education when we compare the occupation of each guardian ${ }^{12}$. 
As shown in Figure 2 below, level of education, occupation, social origin, and race are independent variables for income. As for occupation, the level of education also partially mediates the effects of social origin and race. Thus, the model presupposes a chronological order - from social origin to the setting of salaries, passing through education and occupational allocation - which does not necessarily correspond to all observed cases.

\section{Control variables}

Figure 2 also shows the position of the model's control variables, separated into three blocks, as shown in Table 1. The fact that they are separated into blocks indicates that not all control variables were present in all equations. In general, these control variables include age, kind of family of origin (if single-parent), sex, place of residence, the five geographic regions of the country (North, Northeast, Southeast, South, and Centre-West) and the type of location (rural or urban). Based on Mincer (1974), we included age squared among control variables, which accounts for the nonlinear relationship of this variable with the natural logarithm of income. In addition, we made use of a variable for the years in which individuals worked in their current occupations, which indicates their experience in this specific work.

As usual, all categorical variables were entered as dummies or as a set of dummies into equations, identifying one of the categories as reference, as indicated in Table 1.

\section{RESULTS}

We organized the presentation of data analysis and results as follows: first, we present the main estimated parameters, evaluating direct, indirect, and total effects, focusing on determinants of income and on the role of race and social origin. That information will be enough to test the first and the second hypotheses. In the second segment, then, we make a more detailed and formal comparison between the roles of social origin and race in setting income inequalities between whites and blacks. Through simulations with predicted values, as well as through a comparison between the results estimated by different models, we will be able to test our third hypothesis. 
Before we begin the analysis of estimated parameters, however, we should highlight the fitting of the model to the data - details can be found in Table 2a in the appendices. The model explains $43 \%$ of income, $40 \%$ of occupational status, and $35 \%$ of education variance. Therefore, we can affirm that the estimated model, executed with a final analytical sample of 46,023 cases, presents a good fit to the data.

\section{DIRECT, INDIRECT, AND TOTAL EFFECTS}

In Figure 2, which shows the estimated model, rectangles and ellipses represent the observed variables and the latent variable, respectively. Arrows represent the causal relationships specified for each of the three equations in the model, and values next to arrows are the standardized path coefficients of the direct effects of one variable on the other. Double arrows are the correlations between exogenous variables, while the numbers next to them are correlation coefficients. Small circles represent residuals, whose values are also specified. In addition, although they are not graphically represented, covariations between control variables and other exogenous variables are also present in the estimated mode ${ }^{13}$.

Figure 2

Structural equation model: Graphic representation and standardized direct effects* (Brazil, 2014)

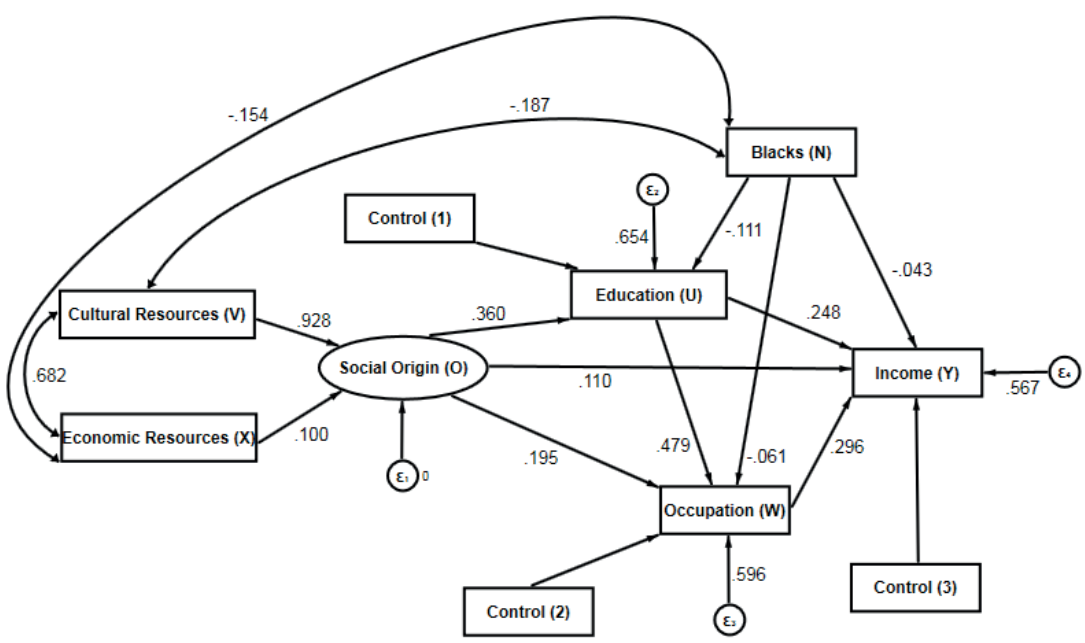

Source: Produced by author based on IBGE (2014).

*All coefficients shown are statistically significant at the level of p. $<0.001$. 
As indicated in Figure 2, the following encoding represents coefficients:

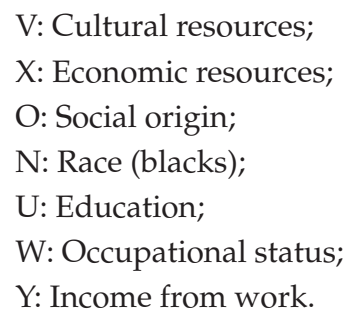

Arrows to the left of Figure 2 show, as one may predict, a high correlation between the variables of economic and cultural resources, which form the social origin $\left[{ }^{r}{ }_{X V}=.682\right]$. Scores resulting from the latent variable vary between $11,622.6$ and $64,686.23$, with a mean of $23,501.86$ and a standard deviation of 9,338.49. As expected, we found a negative correlation between race, cultural resources $\left[_{N V}^{r}=-.187\right]$ and economic capital $\left.{ }^{r}{ }_{N X}=-.154\right]$, so that resulting median social origin scores are smaller for blacks than for whites -19,492.22 and 24,736.84, respectively. Figure 1a, in the Apppendices, clearly shows how the distribution of social origin scores for blacks has a higher concentration within lower values when compared to the distribution among whites. In the estimated model, such difference represents the distance between the starting points of whites and blacks in the process leading to observed income inequalities.

The variable with the greatest direct effect on income is occupation $\left[{ }^{P}{ }_{Y W}=.296\right]$, followed by education $\left[{ }^{P}{ }_{Y U}=.248\right]$, social origin $\left[{ }^{P}{ }_{Y O}=.110\right]$, and race $\left[{ }^{P}{ }_{Y N}=-.043\right]$. Although the direct effect of education is smaller than that of occupation, it is important to remember its indirect effects through occupation, which makes it the variable with the greatest total effects on income. The indirect effects of a variable are calculated by multiplying the coefficients that lead to the target variable. Thus, the indirect effect of education on income is the product of its influence on occupation $\left[{ }^{P}{ }_{W U}=.479\right]$ and its effect on income $\left[{ }^{P}{ }_{Y W}=.296\right]$, resulting in 0.141 . The total effect, in turn, is nothing more than the sum of direct $\left[\begin{array}{l}{ }^{P} \\ { }_{Y U}\end{array}\right]$ and indirect effects $\left[\begin{array}{ll}{ }^{P} & r \\ Y \mathrm{~W} W U\end{array}\right]$. In the case of education, it would be the sum of .248 (direct effects) and .141 (indirect effects), resulting in a total effect of ${ }^{r}{ }_{Y U}=.390$. 
Further to the left of the graphical representation of the model, cultural resources $\left.{ }^{P}{ }_{\text {OV }}=.928\right]$ have a much greater influence than economic resources $\left[{ }^{P}{ }_{\text {OX }}=.100\right]$ on the formation of social origin. Thus, the effects of social origin on other variables translate the influence of cultural capital to a greater extent than the economic capital of the family background. Social origin, in turn, has a weaker direct effect on income $\left[{ }^{P}{ }_{Y O}=.110\right]$, so that its influence is mainly indirect, through education $\left[{ }_{Y Y U}^{P}{ }_{Y{ }_{Y O}}{ }=(.248)^{*}(.360)=0.090\right]$ and, to a lesser extent, through occupation: $\left[{ }^{P}{ }_{Y W W O}^{r}=(.296)^{*}(.195)=.058\right]$. Additionally, social origin has an indirect effect through education and occupation: $\left[{ }^{P}{ }_{Y W}{ }^{r}{ }_{W U}^{r}{ }_{\text {UO }}=\right.$ $\left.(.296)^{*}(.479)^{*}(.360)=.051\right]$.

Thus, total direct and indirect effects of social origin on income can be calculated as follows:

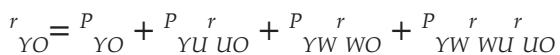

$$
\begin{aligned}
& =(.110)+\left[(.248)^{*}(.360)\right]+\left[(.296)^{*}(.195)\right]+\left[(.296)^{*}(.479)^{*}(.360)\right] \\
& =(.110)+(.090)+(.058)+(.051) \\
& =.309
\end{aligned}
$$

As for the effect of race, as expected, its direct influence on income is negative: $\left[{ }^{P}{ }_{Y N}=-.043\right]$. There is also an effect of race through education

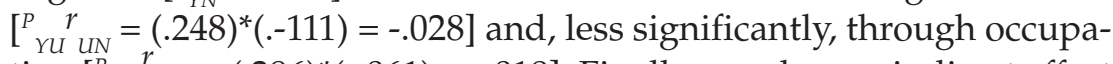
tion $\left[{ }^{P}{ }_{Y W W N}^{r}=(.296)^{*}(-.061)=-.018\right]$. Finally, race has an indirect effect through education and occupation: $\left[{ }^{P} \underset{\gamma W \text { WU }}{r}{ }^{r}{ }_{N N}=(.296)^{*}(.479)^{*}(-.111)=\right.$ -.016]. Thus, the total effects of race on income, combining direct and indirect effects, can be easily calculated:

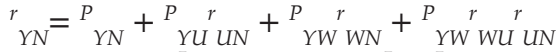

$$
\begin{aligned}
& =(-.043)+\left[(.248)^{*}(-.111)\right]+\left[(.296)^{*}(-.061)\right]+\left[(.296)^{*}(.479)^{*}(-.111)\right] \\
& =(-.043)+(-.028)+(-.018)+(-.016) \\
& =-.105
\end{aligned}
$$

In summary, results presented so far allow us to verify that the total effect of class is greater than the total effect of race, and that the influence of origin occurs more indirectly than the influence of race. However, seeking a more complete interpretation of results, Table 2 provides, besides standardized direct coefficients, the total effects and their decomposition into direct and indirect effects. 
Table 2

Structural equation model: direct, indirect, and total effects (Brazil, 2014)

\begin{tabular}{|c|c|c|c|c|c|c|}
\hline \multirow[t]{3}{*}{ Variable } & \multicolumn{6}{|c|}{ Effects } \\
\hline & \multicolumn{2}{|c|}{ Direct } & \multicolumn{2}{|c|}{ Indirect } & \multicolumn{2}{|c|}{ Total } \\
\hline & coef. & [Std. Coef.] & coef. & [Std. Coef.] & coef. & [Std. Coef.] \\
\hline \multicolumn{7}{|l|}{ Education< } \\
\hline Social origin & $0.0001713^{* * *}$ & {$[0.360]$} & - & - & $0.0001713^{* * *}$ & {$[0.360]$} \\
\hline Blacks & $-0.991^{* * * *}$ & {$[-0.111]$} & - & - & -0.991 & {$[-0.111]$} \\
\hline \multicolumn{7}{|l|}{$\begin{array}{c}\text { Occupa- } \\
\text { tion< }\end{array}$} \\
\hline Social origin & $0.0003745^{* * *}$ & [0.195] & $0.0003307^{* * *}$ & {$[0.172]$} & $0.0007052^{* * *}$ & {$[0.368]$} \\
\hline Blacks & $-2.179^{* * *}$ & {$[-0.061]$} & $-1.914^{* * *}$ & {$[-0.053]$} & $-4.093^{* * *}$ & {$[-0.114]$} \\
\hline Education & $1.930^{* * *}$ & {$[0.479]$} & - & - & $1.930^{* * *}$ & [0.479] \\
\hline \multicolumn{7}{|l|}{ Income< } \\
\hline Social origin & $0.0000104^{* * *}$ & {$[0.110]$} & $0.0000187^{* * *}$ & {$[0.198]$} & $0.0000291^{* * *}$ & [0.309] \\
\hline Blacks & $-0.077^{* * *}$ & {$[-0.043]$} & $-0.108^{* * *}$ & {$[-0.061]$} & $-0.185^{* * *}$ & {$[-0.105]$} \\
\hline Education & $0.049^{* * *}$ & {$[0.248]$} & $0.028^{* * *}$ & [0.141] & $0.077^{* * *}$ & [0.390] \\
\hline Occupation & $0.014^{* * *}$ & {$[0.296]$} & - & - & $0.014^{* * *}$ & {$[0.296]$} \\
\hline \multicolumn{7}{|l|}{$\begin{array}{l}\text { Social } \\
\text { origin< }\end{array}$} \\
\hline $\begin{array}{c}\text { Economic } \\
\text { capital }\end{array}$ & 1 (fixed) & {$[0.100]$} & & - & 1 (fixed) & {$[0.100]$} \\
\hline $\begin{array}{c}\text { Cultural } \\
\text { capital }\end{array}$ & $2979.082^{* * *}$ & {$[0.928]$} & - & - & $2979.082^{* * *}$ & [0.928] \\
\hline
\end{tabular}

Source: Produced by author based on IBGE (2014).

${ }^{*} \mathrm{p}<0.05,{ }^{* *} \mathrm{p}<0.01,{ }^{* * *} \mathrm{p}<0.001$.

Coefficients are vertically organized in accordance with the model's three endogenous variables - education, occupation and income - as well as the latent variable, representing direct, indirect, and total effects on each of them.

The third section of the table from top to bottom shows that an individual being black has a direct effect of -0.077 on their income logarithm; that is, it reduces their income by $-7.4 \%,{ }^{14}$ holding all other variables constant. Each additional year of education, in turn, has a direct effect of $+5.02 \%$ on income, and each additional point on ISEI 
scale increases income by $1.4 \%$. Thus, the direct effect of race on earnings approaches the effect of -1.4 years of study, or -5.2 points on the occupational status scale.

Table 2 also shows that one of the main effects of race is on education itself, so that the fact that an individual is black reduces their school life by almost one year, even when we hold other variables of the first control block constant, as well as social origin. Similarly, a bit further down the table, black individuals tend to have 2.1 points less on the occupational prestige scale. Together, indirect effects of being black reduce income by $-10.2 \%$, as can be inferred from the penultimate column on the right, in which total non-standardized effects are found. Therefore, in addition to having a significant direct effect on income, the indirect effects of race - through education and occupational allocation - must also be considered.

In non-standardized values, the total effect of race on the natural logarithm of income would be -0.185 , which means that the fact that an individual is black tends to reduce their income by $16.8 \%$. In other words, adding the direct effects of race into the setting of wages itself, along with its influence on accumulated years of study and occupational allocation, demonstrates that blacks tend to have a mean income $16.8 \%$ lower than whites, even when we control for the other variables, including social origin.

This is certainly one of the main advantages of using structural equation models. Had we used standard multivariate regression, we would only have identified the direct effect of race, social origin, and other variables on income. However, as results show, their effects are distinct not only in terms of magnitude, but also in terms of composition: the effects of some variables on income are more direct, while the influence of others is more indirect. Figure 3 allows us to better evaluate these distinctions. 
Figure 3

Structural equation model: standardized direct and indirect effects on work income (Brazil, 2014)*

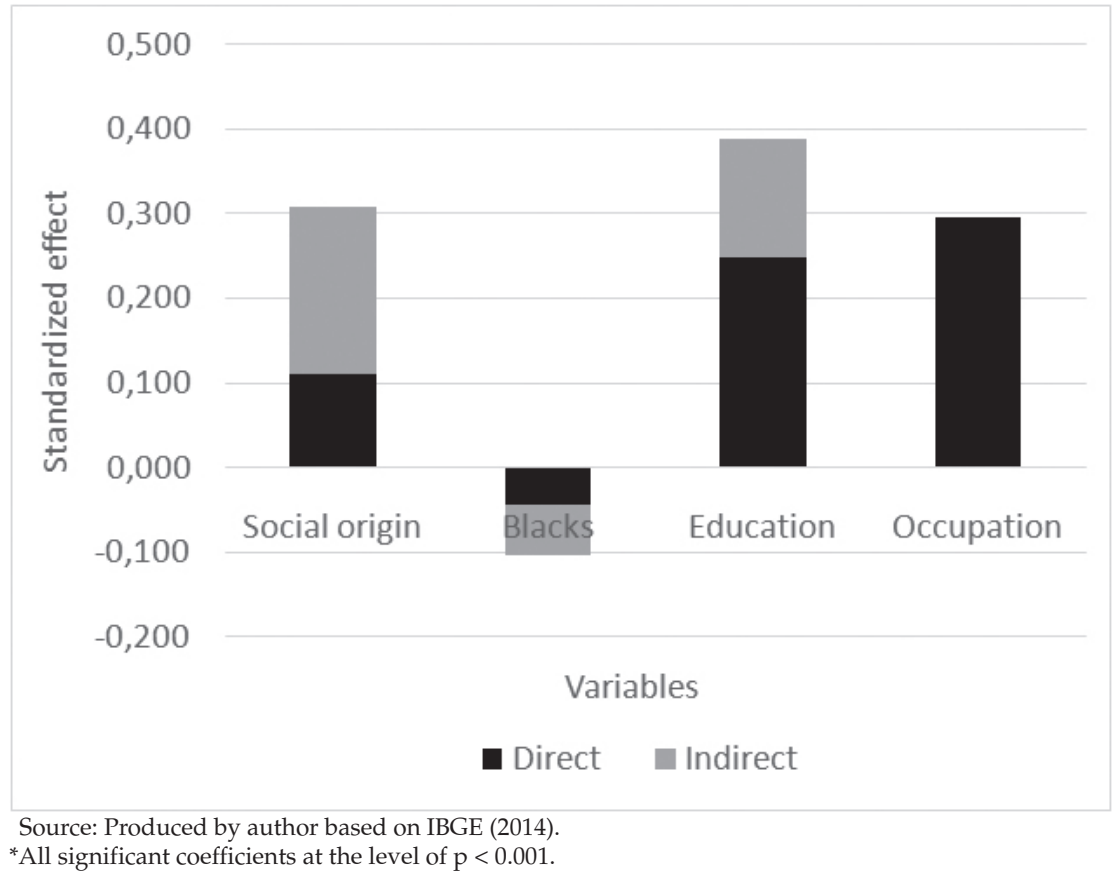

Figure 3 indicates that education has the greatest standardized total effect on income $\left[{ }_{Y U}^{r}=.390\right]$, followed by social origin $\left[{ }_{Y O}^{r}=.309\right]$, occupation $\left[{ }^{r}{ }_{Y W}=.296\right]$, and, finally, race $\left[{ }^{r}{ }_{Y U}=-.105\right]$. However, it also shows that the composition of these effects is very different. While the effect of education is mostly direct, the racial effect, and especially that of social origin, is mostly indirect. With regard to race, more than $55 \%$ of its influence on income is indirect, and, in the case of social origin, this percentage reaches approximately $65 \%$.

According to the results presented in Table 3 , in which we decompose the total effects of race and origin on income, $41 \%$ of the effect of race on income occurs through education, whether or not combined with occupation; $17 \%$ occurs exclusively through occupation; and $41 \%$ occurs directly on income. With regard to social origin, more than $45 \%$ of its total effect is due to education - whether or not combined with occupation,$- 18 \%$ occurs only through occupation, and 35\% occurs directly. 
Table 3

Structural equation model: decomposition of the effects from race and social origin (Brazil, 2014)

\begin{tabular}{lll}
\hline Path & Std. coef. & $\%$ \\
\hline Effects of race & & \\
\hline Blacks $>$ Income & $-0.043^{* * *}$ & 41,6 \\
\hline Blacks $>$ Education $>$ Income & $-0.028^{* * *}$ & 26,3 \\
\hline Blacks $>$ Occupation $>$ Income & $-0.018^{* * *}$ & 17,1 \\
\hline Blacks $>$ Education $>$ Occupation $>$ Income & $-0.016^{* * *}$ & 15,0 \\
\hline TOTAL & $-0.105^{* * *}$ & 100,0 \\
\hline Effects of social origin & & \\
\hline Social origin $>$ Income & $0.110^{* * *}$ & 35,8 \\
\hline Social origin $>$ Education $>$ Income & $0.090^{* * *}$ & 28,9 \\
\hline Social origin $>$ Occupation $>$ Income & $0.058^{* * *}$ & 18,7 \\
\hline Social origin $>$ Education $>$ Occupation $>$ Income & $0.051^{* * *}$ & 16,5 \\
\hline TOTAL & $0.309^{* * *}$ & 100,0 \\
\hline So & & \\
\hline
\end{tabular}

Source: Produced by author based on IBGE (2014).

${ }^{*} \mathrm{p}<0.05,{ }^{* *} \mathrm{p}<0.01,{ }^{* * *} \mathrm{p}<0.001$

Thus, there is a cycle of disadvantages (Hasenbalg and Silva, 2003), in which class and race act at sequential stages, always to the detriment of blacks. This happens, first, because their starting point is less advantageous than that of whites, given the smaller amount of economic and cultural resources from their family of origin. Second, the direct and indirect effects of this initial disadvantage are complemented by barriers conditioned by the racial hierarchy, which are present in schooling, occupational allocation and, finally, at the moment of setting wages, thus producing the inequalities observed between whites and blacks.

Results presented so far, then, corroborate our first and second hypotheses, since we identified significant - direct and indirect - effects of race on income, and, at the same time, we verified that the total effect of social origin on income is greater than the total effect of race, occurring mainly indirectly, through schooling. 
Racial effect and social origin inequalities

The main objective of this section is to measure the degree to which adjusted racial income inequalities could be attributed to social origin. So, in order to test our third hypothesis, we first performed exercises with values predicted by the model.

To generate Figure 4, we calculated predicted values for hypothetical cases, the first of which is a white individual with cultural and economic resources (family origin) identical to the mean of whites in our sample. The second is a black individual with cultural and economic resources also identical to the mean of whites. The third is a white person with the same social origin profile as the mean of blacks. Finally, the last bar to the right represents the expected income of a black person with the same social origin profile as the mean of blacks. Control variables were fixed to their means or modes, while the values of the other mediating endogenous variables (education and occupation) were not fixed a priori ${ }^{15}$.

Hence, height differences between bars within each cluster in Figure 4 represent the total effect of race for individuals with identical social origins - equal to the mean of whites or blacks -, whereas differences between bars of the same colour in different clusters represent the total effect of unequal social origins on whites and blacks.

Figure 4

Structural equation model: predicted monthly income values by social origin profile and race (Brazil, 2014)

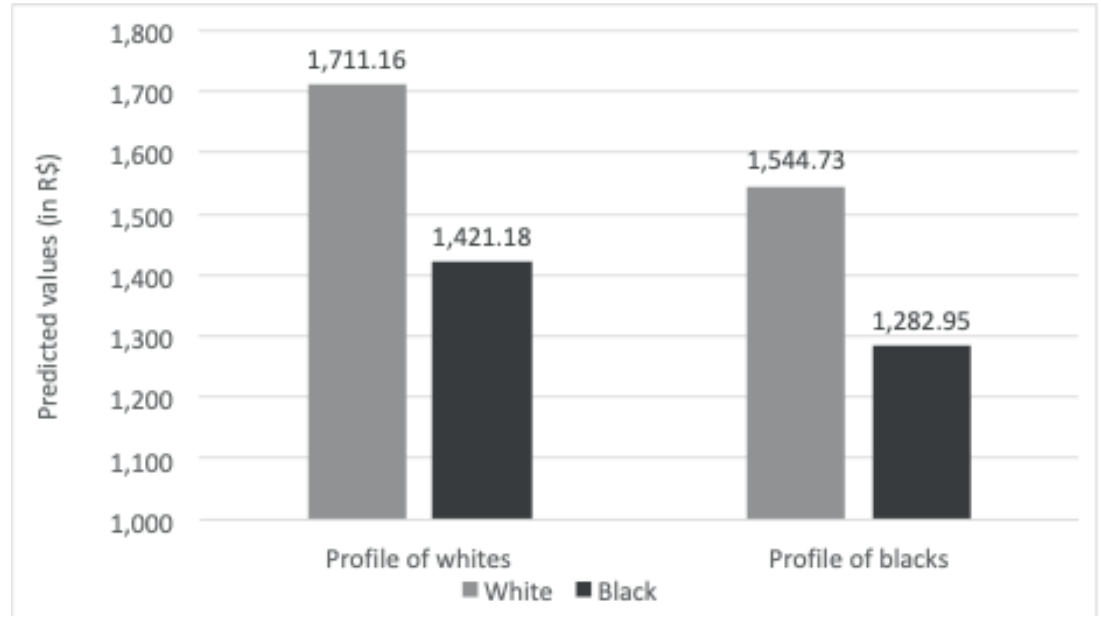

Source: Produced by author based on IBGE (2014). 
The first case - the white individual with a typical white profile - has an expected income of $\mathrm{R} \$ 1,711$. This is much higher than that of the black individual with a profile characteristic of blacks - represented by the last bar -, whose expected income is $\mathrm{R} \$ 1,282$. Thus, the height difference between these bars represents joint total effects of class and race for white and black individuals with cultural and economic resources - family of origin - typical of their corresponding racial categories, resulting in a value which is approximately $25 \%$ lower for blacks.

The second bar shows that if that black person - last bar to the rightcame from a family with a socioeconomic profile similar to the mean of whites - second bar from left to right -, their expected income would increase to $\mathrm{R} \$ 1,421$, thereby reducing their disadvantage to $16.9 \%$ in relation to the white individual. Thus, equalizing social origin would reduce the initial distance in approximately one third - or, to be more precise, $32 \%$-, but racial hierarchy would still be responsible for nearly two thirds of the original distance - or, more precisely, $67 \%$. Therefore, social origin does not seem to explain most adjusted income inequalities between whites and blacks.

Although the above figure provides an excellent illustration to assess the role of race and class in racial income inequalities, we performed the following exercise in order to achieve a more formal separation of both: we executed the structural equation model again. However, we set the effects of social origin on income, education, and occupation to " 0 " (zero) and subsequently compared the effects of race obtained from this restricted model to those of the full model, in which the effects of origin were present. The difference between them is a measure of how much net racial inequality could be attributed to social origin. Figure 5 shows the results of this exercise. 
Figure 5

Structural equation model: net effects (percentage) of race on income, by type of model (Brazil, 2014)*

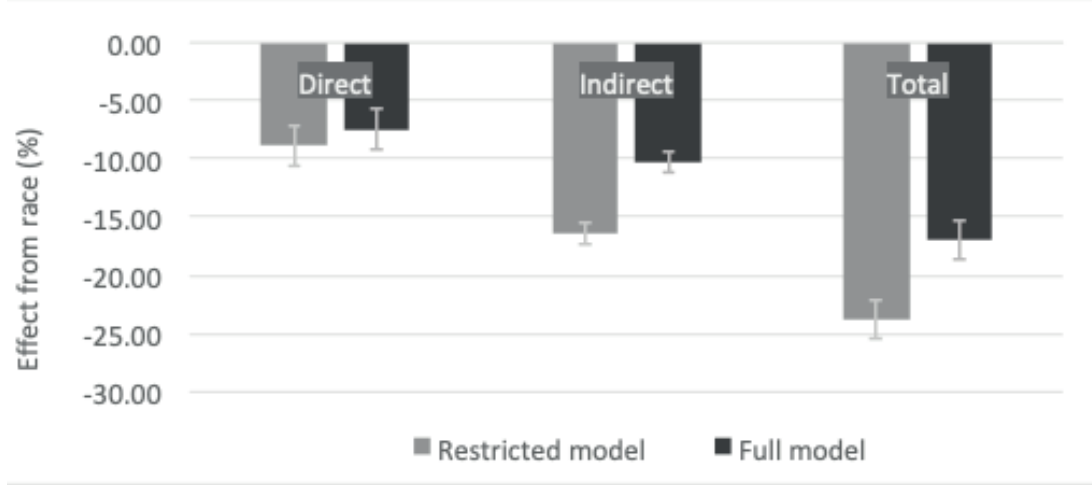

Source: Produced by author based on IBGE (2014).

${ }^{*}$ Lines on top of bars represent the confidence interval (95\%) of estimates.

Figure 5 demonstrates the comparison between two hypothetical individuals representative of white and black categories. Both are identical in terms of age, sex, experience, place of residence, geographical origin, type of family and migratory condition. It shows the extent to which income inequality between them - in favour of whites - could be attributed to the socioeconomic level of the family of origin in terms of total, direct, and indirect effects ${ }^{16}$.

Lighter bars (restricted model) represent the effect of race not controlled by social origin, while darker bars (full model) express the effect of race discounting the effects of the class of origin. The differences between bars, in turn, represent the extent to which adjusted racial inequality can be explained by social origin.

Further to the left of the image, the direct effect of race presents no significant difference between full and restricted models. This means that income inequality between whites and blacks with identical values in the variables used - including education and occupation - cannot be explained by social origin. Regardless of any other variable present in the full model - including social origin - being black has a direct effect of $-7 \%$ on income at the time of setting wages.

However, the consideration of the columns to the centre of the image, which refer to indirect influences, leads to the conclusion that approximately one third of the racial indirect effect can be attributed to social 
origin. The latter has a strong effect on occupation and, especially, on education, thus accounting for a considerable share of the relationship between race and such mediating variables. In other words, a significant amount of the disadvantage of blacks in relation to education and occupational allocation could be accredited to their social origin. Nevertheless, the fact that an individual is black has an impact on their education and/or occupation, regardless of social origin, in a way that their income is reduced by $10 \%$.

Totals, more to the right of the picture, which comprehend direct and indirect effects, show that almost one third of net racial inequality regarding income could be attributed to the socioeconomic level of families of origin. In the restricted model, the total effect of race is $-23 \%$, and, in the full model, it decreases to $-16 \%$. Thus, although a significant amount of the net income inequality between whites and blacks could be attributed to their class, the evidence shows that race itself seems to be responsible for a larger portion than social origin.

Hence, results deny our third hypothesis, which states that social origin disparities could explain most adjusted inequalities observed between whites and blacks mean income.

\section{CONCLUSIONS}

Results have enabled a better understanding of the main paths through which race and social origin affect income, as well as of the weight of each of these principles of stratification on the process leading to income gaps between blacks and whites in Brazil.

First, they indicated that the current total effect of social origin on income from work is greater than the effect of race. Economic and, in particular, cultural resources of families of origin have strong - direct and, especially, indirect - effects on income, which, on the whole, are higher than the effects of race. A significant share of the effects of race on income - especially its indirect influence through education and occupation - can, therefore, be attributed to the different starting points of blacks and whites. 
At the same time, results corroborate the premise according to which there are significant direct and indirect effects of race on income, even when we hold other variables constant, including social origin. When compared to whites who share similar characteristics, such as geographic region, age, sex and social origin, black individuals tend to suffer disadvantages. This racial effect occurs directly, reducing the income of blacks by $7.4 \%$, but also indirectly, through education and occupation. In total, directly and indirectly, being black tends to reduce individuals' income by $16.8 \%$. Also, approximately $55 \%$ of the race effect and $65 \%$ of the social origin effect on income occur indirectly, especially through education.

Just as indicated by studies conducted in other countries (Hout and DiPrete, 2006), education also plays an interesting role in the Brazilian stratification system: it is the most important channel through which racial and class inequalities are reproduced. However, at the same time, class, race and the other variables leave more than $65 \%$ of their variation unexplained, which also makes education one of the main paths for the social mobility of black individuals and/or those from lower classes. For this reason, policies specifically aimed at reducing educational inequalities between whites and blacks may be one of the most effective strategies for reducing racial distances in terms of income and occupational status ${ }^{17}$.

Furthermore, results revealed that social origin disparities could not explain most adjusted income inequalities between blacks and whites. Therefore, they cast doubt on claims which rank class as more relevant than race in explaining racial income gaps in Brazil (Osorio, 2009; Arias, Yamada and Tejerina, 2004; Silva, 2000). Reinforcing some of the conclusions drawn by Silva (1988), evidence indicates that, if we consider both direct and indirect effects, the income gap between whites and blacks should be attributed more to racial hierarchy than to social origin. Nonetheless, given the known limitations of this kind of analysis, which is very sensitive to specification bias, it is recommended to exercise caution in interpreting these results.

Results do, however, confirm that, more than 130 years after the abolition of slavery in Brazil, the black population still suffers a double disadvantage. Due to the historical legacy of four centuries of slavery, they tend to be born into families with a lower stock of economic and cultural resources, which has direct and indirect effects - especially 
through education - on their income in the future. Additionally, they face disadvantages due to their racial category, which manifest themselves at different moments of their life cycle: in school results, occupational allocation, and, finally, in the setting of wages.

Thus, it is necessary to recognize race as a resilient construct, still capable of strongly shaping our social relations (Meer and Nayak, 2015), fixing a hierarchy among individuals and, therefore, facilitating or hindering access to opportunities and resources distributed by society. It is likely that its present relevance derives not only from an archaism, a mere legacy of the racial relationships of a slavery past in the process of being overcome, but that contemporary social hierarchies themselves, elaborated by the dynamics of the most modern sectors of society, are also legitimized by respecting the criteria of social hierarchy present in wider society, incorporating and updating them continuously, and this way maintaining race as an important criterion of social classification (Bowles, 1973; Blumer, 1965) ${ }^{18}$.

In a famous study based on data from a representative survey of the Brazilian population ${ }^{19}$, Almeida and Young (2007) verified that, besides Brazilians' willingness to classify each other in racial terms, they also attribute specific qualities, characteristics, and positions in an occupational hierarchy to different racial categories - white, brown, and black $^{20}$. Thus, while whites tended to be associated with qualities such as intelligence and a high-level of schooling and education, brown and black-skinned individuals were more often labelled as criminals, tricksters and poor. Moreover, whites were more often assigned high-status occupations, such as lawyer and teacher, while blacks were identified with lower-status occupations, such as doormen, garbage collectors, and shoe shiners. Therefore, racial classification in Brazil continues to impose a hierarchy on individuals, assigning negative qualities and characteristics to blacks and browns, as well as identifying them, by principle, with inferior social positions.

We have good reason to believe that the results here presented - which demonstrated the disadvantages experienced by blacks in several moments of their lives, leading to an income significantly lower than that of whites - reflect combined effects of racial hierarchy. As a result, blacks are given unequal treatment, the consequences of which are felt at an early age - harming, as we have seen, their school life -, as well as in later moments, such as in occupational allocation and/or in the 
setting of salaries. A better understanding of the mechanisms by which racial hierarchy exerts such influences is a fundamental question, and it is one of the great challenges posed to the researchers concerned with this theme. Nevertheless, it goes beyond the scope of this work.

Despite its limitations, we are confident that, in bringing a new, detailed and updated analysis to a long-standing debate, the results obtained here contribute to a better understanding of the stratification process which end up generating the inequalities observed between whites and blacks within the Brazilian labour market. Nevertheless, more detailed studies of the mechanisms by which the observed effects manifest would greatly contribute to understanding this phenomenon as well as to our ability to combat it.

(Recebido para publicação em 3 de junho de 2018)

(Reapresentado em 14 de março de 2019)

(Reapresentado em 24 de junho de 2019)

(Aprovado para publicação em 10 de novembro de 2019)

\section{NOTES}

1. We understand classes as aggregates of individuals whose initial life conditions, provided by families, allow access to similar volumes and structures of cultural and economic resources, which are able to condition - to a greater or lesser degree - one's life chances. For this reason, in this article we use the terms "class" and "social origin" as synonyms.

2. Racial data in PNAD are based on self-identification. The "blacks" category comprehends "black-skinned" and "brown-skinned" people. The latter is an intermediate classification between "whites" and "blacks", in accordance with phenotypic characteristics, especially skin color. As better explained and justified later, in this article we aggregate blacks and browns into the same category.

3. Some authors believe that it is even possible that the weight of race as a stratifying principle increases as society becomes more competitive, since classes and fractions of privileged classes may begin to use racism as a mechanism to block growing competition for the most valued positions (Bonacich, 1972; Cox, 1948).

4. Most of these studies - just like the present paper - seek to measure racial discrimination based on the net effect of the "race" variable on the phenomenon under analysis, which is not affected by other relevant variables, such as education, social origin, place of residence and so forth. However, it is always important to remember that there are important limitations in establishing causal relationships through this type of procedure, especially due to the possible omission of other relevant variables (Goldthorpe, 2000).

5. We restricted our review to works which take income as the dependent variable. For a broader perspective on class, race and stratification in Brazil, see Souza, Ribeiro and Carvalhaes (2010) and Ribeiro (2006). 
6. The advantage of running separate models, nonetheless, is that slopes can vary for different race groups.

7. See IBGE (2014).

8. Table $1 \mathrm{a}$, in the appendices, shows the basic statistics of the variables used in the model.

9. With very few exceptions, self-declared race is the only measure available in most databases regarding Brazilian population. Despite its well-known limitations (Telles and Lim, 1998), Osorio (2009) has shown that there is a considerable correspondence between respondents self-definition and interviewers' classification.

10. One of the advantages of the latest statistical packages for structural equation models is the possibility of jointly estimating latent variables and the structural part of models (Acock, 2013).

11. As we input the same values regardless of the age group, we are assuming there is something structural in the socioeconomic hierarchy of occupations which does not change substantively over the years. Despite methodological limitations imposed by such an assumption, in fact correlations between average schooling and median income of occupations over the last decades are strong and significant: for instance, median income of occupations for 2015 shows a correlation of 0.873 with those of 1985 . As for schooling, the correlation between 2015 and 1985 is 0.904 .

12. Although the PNAD 2014 database provides information about parents' education, its use would include an additional four thousand missing (non-weighted) cases to the model in comparison with data about parents' occupation. Besides, as expected, such missing information is far from random, but rather strongly related to variables such as educational attainment and race. Nevertheless, I tested the results for models in which parents' education - measured as years of schooling - was added to social origin variables, and there was no statistically significant change (at 95\% level) in race coefficients. Adding this variable, or using it instead of parents' occupation, would not change the main conclusions of the study.

13. Table 3a, in appendices, shows all coefficients, their errors, and the test of significance.

14. To obtain the percentage effect on income, we apply the following formula to the non-standardized coefficient: $[\operatorname{Exp}(b)-1] * 100$.

15. For imputed values, see Table $4 \mathrm{a}$ in appendices.

16. The values of the mediating endogenous variables (education and occupational status) were not fixed a priori.

17. The substantial and persistent effects of race on educational achievement in Brazil have been studied by authors such as Fernandes (2004), Lima and Prates (2015), and Soares and others (2005).

18. Those arguments are highly speculative in light of the empirical findings of this paper.

19. The same data were also used by Bailey (2008).

20. In this study, respondents were presented photos of similar individuals with different phenotypic characteristics. They were then stimulated to classify these individuals in racial terms and, subsequently, to relate them to previously selected characteristics and occupations. 


\section{REFERENCES}

ACOCK, Alan C. (2013), Discovering Structural Equation Modeling Using Stata. Lakeway: Stata Press.

ALMEIDA, Alberto Carlos; YOUNG, Clifford Alexander. (2007), A cabeça do brasileiro. Rio de Janeiro: Record.

ARCAND, Jean Louis; D'HOMBRES, Béatrice. (2004), "Racial discrimination in the Brazilian labour market: Wage, employment and segregation effects". Journal of International Development, v. 16, n. 8, pp. 1053-1066.

ARIAS, Omar; YAMADA, Gustavo; TEJERINA, Luis. (2004), “Education, family background and racial earnings inequality in Brazil". International Journal of Manpower, v. 25, n. 3-4, pp. 355-374.

BAILEY, Stanley R.; LOVEMAN, Mara; MUNIZ, Jeronimo O. (2013), "Measures of 'race' and the analysis of racial inequality in Brazil". Social Science Research, v. 42, n. 1, pp. 106-119.

BAILEY, Stanley R. (2008), “Unmixing for race making in Brazil”. American Journal of Socio$\log y$, v. 114, n. 3, pp. 577-614.

BAILEY, Stanley R. (2004), "Group dominance and the myth of racial democracy: Antiracism attitudes in Brazil". American Sociological Review, v. 69, n. 5, pp. 728-747.

BERTRAND, Marianne; MULLAINATHAN, Sendhil. (2004), “Are Emily and Greg more employable than Lakisha and Jamal? A field experiment on labor market discrimination". The American Economic Review, v. 94, n. 4, pp. 991-1013.

BLAU, Peter M.; DUNCAN, Otis Dudley. (1967), The American Occupational Structure. New York: Free Press.

BLUMER, Herbert. (1965), "Industrialization and race relations”. In: G. Hunter (ed.), Industrialization and Race Relations. London: Oxford University Press, pp. 220-253.

BOLIVER, Vikki. (2016), "Exploring ethnic inequalities in admission to Russell Group universities". Sociology, v. 50, n. 2, pp. 247-266.

BONACICH, Edna. (1972), "A theory of ethnic antagonism: The split labor market". American Sociological Review, v. 37, n. 5, pp. 547-559.

BOWLES, Samuel. (1973), "Understanding unequal economic opportunity". The American Economic Review, v. 63, n. 2, pp. 346-356.

CARDOSO, Fernando Henrique. (1977), Capitalismo e escravidão no Brasil meridional: o negro na sociedade escravocrata do Rio Grande do Sul. Rio de Janeiro: Paz e Terra.

CARVALHO, José Murilo de. (2001), Cidadania no Brasil. O longo caminho. Rio de Janeiro: Civilização Brasileira.

COX, Oliver Cromwell. (1948), Caste, class, E race: a study in social dynamics. New York: Doubleday.

FEAGIN, Joe R. (1991), "The continuing significance of race: antiblack discrimination in public places". American Sociological Review, v. 56, n. 1, pp. 101-116. 
FERNANDES, Danielle Cireno. (2004), "Race, socioeconomic development and the educational stratification process in Brazil". Research in Social Stratification and Mobility, v. 22, pp. 365-422.

FERNANDES, Florestan. (1965), A integração do negro à sociedade de classes. São Paulo: Dominus.

FIGUEIREDO SANTOS, José Alcides. (2005), "Efeitos de classe na desigualdade racial no Brasil". DADOS - Revista de Ciências Sociais, v. 48, n. 1, pp. 21-65.

FREYRE, Gilberto. (1986 [1933]), Casa-grande e senzala. Berkeley: University of California Press.

GANZEBOOM, Harry B.G.; DE GRAFF Paul M.; TREIMAN, Donald. (1992), “A standard international socio-economic index of occupational status". Social Science Research, v. 21, n. 1 , pp. $1-56$.

GOLDTHORPE, John H. (2000), On sociology: numbers, narratives, and the integration of research and theory. Oxford: Oxford University Press.

GUIMARÃES, Antonio Sérgio Alfredo. (1999), Racismo e anti-racismo no Brasil. São Paulo: Editora 34.

HASENBALG, Carlos Alfredo; SILVA, Nelson do Vale. (2003), Origens e destinos: desigualdades sociais ao longo da vida. Rio de Janeiro: IUPERJ/UCAM.

HASENBALG, Carlos Alfredo. (1979), Discriminação e desigualdades raciais no Brasil. Rio de Janeiro: Graal.

HOUT, Michael; DiPRETE. (2006), “What we have learned: RC28's contributions to knowledge about social stratification". Research in Social Stratification and Mobility, v. 24, n. 1, pp. 1-20.

IBGE - Instituto Brasileiro de Geografia e Estatística. (2014), Pesquisa nacional por amostra de domicílios (PNAD). Rio de Janeiro, IBGE. Retrieved from ftp:/ / ftp.ibge.gov.br/Trabalho_e_Rendimento/Pesquisa_Nacional_por_Amostra_de_Domicilios_anual/microdados/2014/ on Dec. 252017.

KERR, Clark et al. (1960), Industrialism and industrial man. Cambridge: Harvard University Press.

LIMA, Márcia; PRATES, Ian. (2015), “Desigualdades raciais no Brasil: um desafio persistente". In: M.T.S. Arretche (org.), Trajetórias das desigualdades: como Brasil mudou nos últimos 50 anos. São Paulo: Editora UNESP.

MASSEY, Douglas S. (2007), Categorically Unequal: The American Stratification System. New York: Russell Sage Foundation.

. (1990), "American apartheid: Segregation and the making of the underclass". American Journal of Sociology, v. 96, n. 2, pp. 329-357.

MEER, Nasar; NAYAK, Anoop. (2015), "Race ends where? Race, racism and contemporary sociology". Sociology, v. 49, n. 6, pp. NP3-NP20.

MINCER, Jacob. (1974), Schooling, experience and earnings. New York: Columbia University Press. 
MONK JR., Ellis P. (2016), "The consequences of 'race and color' in Brazil". Social Problems, v. 63 , n. 3, pp. $413-430$.

O GLOBO. (2017), Secretário de Educação do Rio critica palestra de Taís Araújo: ‘Idiotice racial'. (2017). O Globo, 21 nov. 2017. Retrieved from https://oglobo.globo.com/rio/ secretario-de-educacao-do-rio-critica-palestra-de-tais-araujo-idiotice-racial-22094643 .

OSORIO, Rafael Guerreiro. (2009), A desigualdade racial de renda no brasil: 1976-2006. Tese (Doutorado em Sociologia), Universidade de Brasília, Brasília.

PARSONS, Talcott. (1940), "An analytical approach to the theory of social stratification". American Journal of Sociology, v. 45, n. 6, pp. 841-862.

PIERSON, Donald. (1967), Negroes in Brazil: a study of race contact at Bahia. Illinois: Southern Illinois University Press.

PINTO, Luiz de Aguiar Costa. (1953), O negro no Rio de Janeiro: relações de raças numa sociedade em mudança. Rio de Janeiro: Brasiliana.

RIBEIRO, Carlos Antonio Costa. (2006). "Class, race, and social mobility in Brazil". DADOS - Revista de Ciências Sociais, v. 49, n. 4, pp. 833-873.

ROLLOCK, Nicola. (2014), "Race, class and 'the harmony of dispositions'". Sociology, v. 48, n. 3 , pp. $445-451$.

SILVA, Nelson do Valle. (2000), "A research note on the cost of not being white in Brazil". Studies in Comparative International Development, v. 35, n. 2, pp. 18-27.

. (1988), "Cor e processo de realização socioeconômica". In: C. Hasenbalg e N. do V. Silva (eds.), Estrutura social, mobilidade e raça. São Paulo: Vértice; Editora Revista dos Tribunais, pp. 144-163.

(1985), “Updating the Cost of Not Being White in Brazil". In: P.M Fontaine (ed.), Race, Class and Power in Brazil. Los Angeles: UCLA Press, pp. 42-55.

. "O preço da cor: diferenciais raciais na distribuição de renda no Brasil". Pesquisa e Planejamento Econômico, v. 10, n. 1, pp. 21-44.

. (1978), Black-white Income Differentials: Brazil, 1960. Tese (Doutorado em Sociologia), University of Michigan, Ann Harbor.

SOARES, Sergei, et al. (2005), Os mecanismos de discriminação racial nas escolas brasileiras. Rio de Janeiro: IPEA.

SOUZA, Pedro Ferreira de; RIBEIRO, Carlos Antonio Costa; CARVALHAES, Flavio. (2010), Desigualdade de oportunidades no Brasil: considerações sobre classe, educação e raça. Revista Brasileira de Ciências Sociais, v. 25, n. 73, pp. 77-84.

STEELE, Claude. (2003), "Stereotype thread and African-American student achievement". In: T. Perry; C. Steele; A. Hillard (eds.), Young, gifted, and black: promoting high achievement among African-American Students. Boston: Beacon Press, pp. 109-130.

TELLES, Edward Eric. (2003), Racismo à brasileira: uma nova perspectiva sociológica. Rio de Janeiro: Relume Dumará.

TELLES, Edward; BAILEY, Stanley. (2013), “Understanding Latin American beliefs about racial inequality". American Journal of Sociology, v. 118, n. 6, pp. 1559-1595. 
André Salata

TELLES, Edward E.; LIM, Nelson. (1998), “Does it matter who answers the race question? Racial classification and income inequality in Brazil". Demography, v. 35, n. 4, pp. 465-474.

TREIMAN, Donald J. (1970), "Industrialization and social stratification". Sociological Inquiry, v. 40 , n. 2, pp. 207-234.

WAGLEY, Charles. (1952), "Race relations in an Amazon community". In: C. Wagley (ed.), Race and Class in Rural Brazil. Paris: UNESCO, pp. 116-141.

WILSON, William Julius. (1987), The truly disadvantaged: the inner city, the underclass, and public policy. Chicago: University of Chicago Press.

. (1978), The declining significance of race: blacks and changing American Institutions. Chicago, University of Chicago Press.

WRIGHT, Erik Olin. (1978), "Race, class, and income inequality". American Journal of Sociology, v. 83, n. 6 , pp. $1368-1397$. 


\section{APPENDICES}

Table 1a

Structural equation model: descriptive statistics (Brazil, 2014)

\begin{tabular}{lcccc}
\hline Variable & Mean & $\begin{array}{c}\text { Standard } \\
\text { deviation }\end{array}$ & Minimum & Maximum \\
\hline Education (in years) & 8.63 & 4.43 & 0.00 & 15.00 \\
\hline Occupation (ISEI) & 36.65 & 17.87 & 16.00 & 90.00 \\
\hline Income / workload (ln) & 1.99 & 0.86 & -5.37 & 8.01 \\
\hline Economic resources (origin) & $1,196.80$ & 936.14 & 192.00 & $20,000.00$ \\
\hline Cultural resources (origin) & 7.49 & 2.91 & 3.70 & 15.00 \\
\hline Blacks & 0.54 & 0.50 & 0.00 & 1.00 \\
\hline Region of origin 1 (North) & 0.07 & 0.26 & 0.00 & 1.00 \\
\hline Region of origin 2 (Northeast) & 0.31 & 0.46 & 0.00 & 1.00 \\
\hline Region of origin 4 (South) & 0.15 & 0.36 & 0.00 & 1.00 \\
\hline Region of origin 5 (Centre-west) & 0.06 & 0.24 & 0.00 & 1.00 \\
\hline Place of origin 2 (Urban) & 0.59 & 0.49 & 0.00 & 1.00 \\
\hline Place of origin 3(Urban-Capital) & 0.30 & 0.46 & 0.00 & 1.00 \\
\hline Family of origin (single parent) & 0.28 & 0.45 & 0.00 & 1.00 \\
\hline Women & 0.53 & 0.50 & 0.00 & 1.00 \\
\hline Age & 39.83 & 12.44 & 20.00 & 64.00 \\
\hline Age ${ }^{2}$ & $1,740.92$ & $1,030.61$ & 400.00 & $4,096.00$ \\
\hline Current region 1 (North) & 0.08 & 0.27 & 0.00 & 1.00 \\
\hline Current region 2 (Northeast) & 0.27 & 0.44 & 0.00 & 1.00 \\
\hline Current region 4 (South) & 0.15 & 0.36 & 0.00 & 1.00 \\
\hline Current region 5 (Centre-west) & 0.07 & 0.26 & 0.00 & 1.00 \\
\hline Current location 2 (Urban) & 0.55 & 0.50 & 0.00 & 1.00 \\
\hline Current location 3 (Urban & 0.31 & 0.46 & 0.00 & 1.00 \\
\hline metropolitan) & 0.13 & 0.33 & 0.00 & 1.00 \\
\hline Migration & 8.01 & 9.50 & 0.00 & 59.00 \\
\hline Yoars & & & \\
\hline
\end{tabular}

Source: Produced by author based on IBGE (2014). 
Table 2a

Structural equation model: fit statistics (Brazil, 2014)

\begin{tabular}{lcccc}
\hline \multirow{2}{*}{ Endogenous variables } & \multicolumn{3}{c}{ Variance } & \multirow{2}{*}{ R-squared } \\
\cline { 2 - 4 } & fitted & predicted & residual & \\
\hline Education & 19.59 & 6.76 & 12.82 & 0.35 \\
\hline Occupation & 317.88 & 128.14 & 189.73 & 0.40 \\
\hline Income & 0.77 & 0.33 & 0.44 & 0.43 \\
\hline $\mathrm{N}$. & \multicolumn{3}{c}{46.023} \\
\hline Source: Produced by author based on IBGE (2014).
\end{tabular}


Table 3a

Structural Equation Model: estimated parameters (Brazil, 2014)

\begin{tabular}{lccc}
\hline Variables & Coef. & $\begin{array}{c}\text { Robust stand- } \\
\text { ard error }\end{array}$ & Std. Coef. \\
\hline Education < & & & \\
\hline Social origin & $0.000171^{* * *}$ & 0.000 & 0.360 \\
\hline Blacks & $-0.991^{* * *}$ & 0.045 & -0.111 \\
\hline Region of origin (North) & $-0.350^{* * *}$ & 0.067 & -0.020 \\
\hline Region of origin (Northeast) & $-0.919^{* * *}$ & 0.053 & -0.096 \\
\hline Region of origin (South) & $-0.204^{* * *}$ & 0.059 & -0.017 \\
\hline Region of origin (Centre-west) & $-0,094$ & 0.075 & -0.005 \\
\hline Place of origin (urban) & $1.667^{* * *}$ & 0.064 & 0.185 \\
\hline Place of origin (urban-capital) & $2.195^{* * *}$ & 0.072 & 0.227 \\
\hline Family of origin (single-parent) & $-0.568^{* * *}$ & 0.046 & -0.057 \\
\hline Women & $0.585^{* * *}$ & 0.041 & 0.066 \\
\hline Age & $-0.0844^{* * *}$ & 0.002 & -0.237 \\
\hline Constant & $7.121^{* * *}$ & 0.121 & 1.609 \\
\hline Status of the occupation $<$ & & & \\
\hline Education & $1.930^{* * *}$ & 0.028 & 0.479 \\
\hline Social origin & $0.0003745^{* * *}$ & 0.000 & 0.195 \\
\hline Blacks & $-2.179^{* * *}$ & 0.205 & -0.061 \\
\hline Women & $-0.859^{* * *}$ & 0.189 & -0.024 \\
\hline Age & $0.123^{* * *}$ & 0.009 & 0.085 \\
\hline Current region (North) & $0.561^{*}$ & 0.284 & 0.008 \\
\hline Current region (Northeast) & $0.856^{* * *}$ & 0.233 & 0.021 \\
\hline Current region (South) & 0.146 & 0.279 & 0.003 \\
\hline Current region (Centre-west) & $1.107^{* * *}$ & 0.318 & 0.016 \\
\hline Current location (urban) & $4.844^{* * *}$ & 0.249 & 0.135 \\
\hline Current location (urban-metropolitan) & $5.744^{* * *}$ & 0.293 & 0.149 \\
\hline Migration & $0.776^{* * *}$ & 0.291 & 0.014 \\
\hline Constant & $2.242^{* * *}$ & 0.534 & 0.126 \\
\hline Income < & & & \\
\hline & & & \\
\hline
\end{tabular}


Table 3a

Structural Equation Model: estimated parameters (Brazil, 2014) (Cont.)

\begin{tabular}{lccc}
\hline Variables & Coef. & $\begin{array}{c}\text { Robust stand- } \\
\text { ard error }\end{array}$ & Std. Coef. \\
\hline Education & $0.0492^{* * *}$ & 0.002 & 0.248 \\
\hline Occupation & $0.0146^{* * *}$ & 0.000 & 0.296 \\
\hline Social origin & $0.0000104^{* * *}$ & 0.000 & 0.110 \\
\hline Blacks & $-0.0772^{* * *}$ & 0.010 & -0.043 \\
\hline Women & $-0.264^{* * *}$ & 0.009 & -0.153 \\
\hline Age & $0.0492^{* * *}$ & 0.003 & 0.708 \\
\hline Current region (North) & $-0.0901^{* * *}$ & 0.015 & -0.028 \\
\hline Current region (Northeast) & $-0.319^{* * *}$ & 0.012 & -0.163 \\
\hline Current region (South) & $0.0386^{* *}$ & 0.012 & 0.016 \\
\hline Current region (Centre-west) & $0.0644^{* * *}$ & 0.014 & 0.020 \\
\hline Current location (urban) & $0.0985^{* * *}$ & 0.017 & 0.057 \\
\hline Current location (urban-metropolitan) & $0.188^{* * *}$ & 0.018 & 0.101 \\
\hline Migration & $0.117^{* * *}$ & 0.014 & 0.045 \\
\hline Age & $-0.000485^{* * *}$ & 0.000 & -0.579 \\
\hline Years & $0.00764^{* * *}$ & 0.001 & 0.084 \\
\hline Constant & $-0.332^{* * *}$ & 0.057 & -0.378 \\
\hline Social origin $<$ & & & \\
\hline Economic resources & 1.000 & $()$. & 0.100 \\
\hline Cultural resources & $2979.1^{* * *}$ & 569 & 0.928 \\
\hline
\end{tabular}

Source: Produced by author based on IBGE (2014).

${ }^{*} \mathrm{p}<0.05 .{ }^{* *} \mathrm{p}<0.01 .{ }^{* * *} \mathrm{p}<0.001$ 
Table 4a

Structural equation model: imputed values for the calculation of predicted income

\begin{tabular}{lcc}
\hline \multirow{2}{*}{ Profile } & \multicolumn{2}{c}{ Social origin } \\
\cline { 2 - 3 } & Income & Education \\
\hline Profile of whites & $1,344.65$ & 8.05 \\
\hline Profile of blacks & $1,061.58$ & 6.97 \\
\hline
\end{tabular}

Source: Produced by author based on IBGE (2014).

Figure 1a

Boxplot: distribution of scores for social origin (latent variable), for whites and blacks (Brazil, 2014)

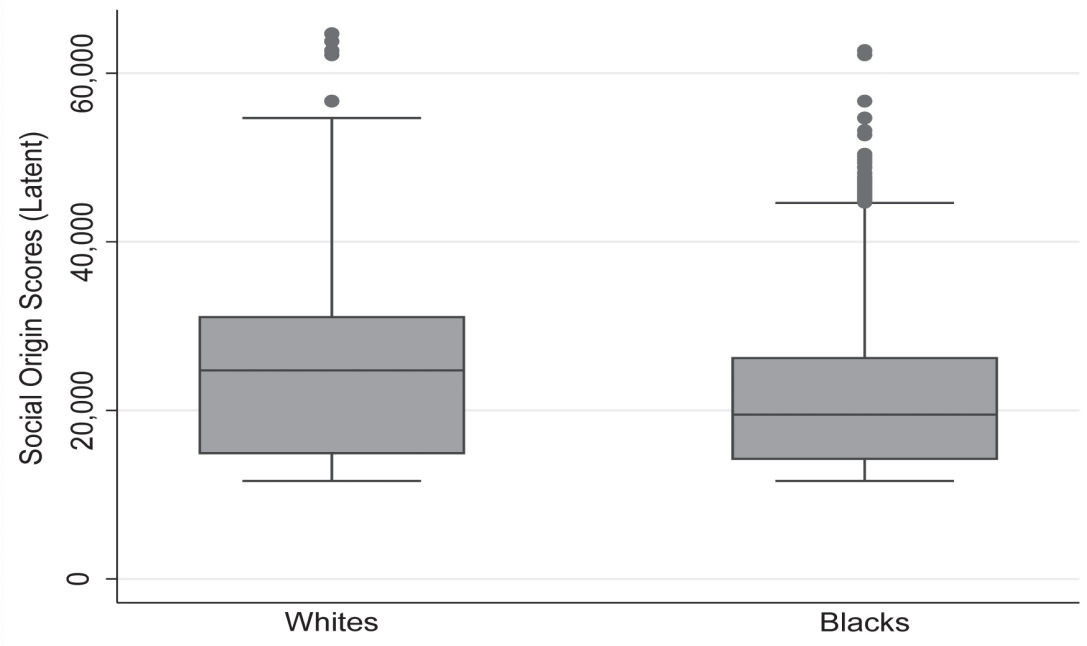

Source: Produced by author based on IBGE (2014). 


\section{RESUMO}

Raça, Classe e Desigualdade de Rendimentos no Brasil: Uma Análise de Trajetória Social

O artigo trata da relação entre raça, classe e rendimentos no Brasil, com o objetivo principal de investigar os determinantes das desigualdades raciais no mercado de trabalho do país. Ao fazer uso de modelos de equações estruturais, analisamos o processo de estabelecimento de diferenciais de renda entre brancos e negros, desde sua origem social até a definição de salários, através da escolarização e alocação ocupacional. A análise, com base nos dados da Pesquisa Nacional por Amostra de Domicílios coletada em 2014 permite comparar os efeitos diretos, indiretos e totais da raça e origem social sobre a renda do trabalho. Os resultados mostram que, embora os efeitos totais de origem social sejam maiores que os efeitos raciais, o primeiro não pode explicar a maior parte das desvantagens sofridas pelos negros atualmente no Brasil, que ocorrem principalmente de modo indireto - através da educação e da ocupação. Assim, o artigo traz evidências novas, atualizadas e mais detalhadas para um debate de longa data.

Palavras-chave: desigualdade de renda; raça; classe; estratificação social; trajetórias sociais

\section{ABSTRACT \\ Race, Class and Income Inequality in Brazil: A Social Trajectory Analysis}

The article deals with the relationship between race, class and income in Brazil, with the main objective of investigating the determinants of racial inequality in the country's labour market. By making use of structural equation models, it analyses the process of setting income differentials between whites and blacks, from their social origin to the definition of wages, through schooling and occupational allocation. The analysis, based on data from the Brazilian National Household Sample Survey, collected in 2014, allows us to compare direct, indirect and total effects of race and social origin on income from work. Results show that, although the total effects of social origin are larger than racial effects, the former cannot explain most disadvantages suffered by blacks nowadays in Brazil, which occur mainly indirectly - through education and occupation. Thus, the study brings new, updated and more detailed evidence to a long-standing debate.

Keywords: income inequality; race; class; social stratification; social trajectories 


\section{RÉSUMÉ \\ Race, Classe et Inégalité des Revenus au Brésil: Une Analyse de la Trajectoire Social}

L'article traite de la relation entre la race, la classe et le revenu au Brésil, ayant pour objectif principal d'étudier les déterminants des inégalités raciales sur le marché du travail du pays. Lorsque nous utilisons des modèles d'équations structurelles, nous analysons le processus d'établissement des écarts de revenus entre les blancs et les noirs, de leurs origines sociales à la définition des salaires, en passant par la scolarisation et la répartition professionnelle. L'analyse, basée sur les données de l'Enquête nationale par sondage sur les ménages (Pesquisa Nacional por Amostra de Domicílios), collectée en 2014, permet de comparer les effets directs, indirects et totaux de la race et de l'origine sociale sur le revenu du travail. Les résultats montrent que, bien que les effets totaux de l'origine sociale soient supérieurs aux effets raciaux, les premiers ne peuvent expliquer la plupart des désavantages subis par les noirs au Brésil aujourd'hui, qui se produisent principalement de façon indirecte par l'éducation et par la profession. Ainsi, l'article apporte des preuves nouvelles, actualisées et plus détaillées à un débat de longue date.

Mots-clés: inégalité des revenus; race; classe; stratification sociale; trajectoires sociales

\section{RESUMEN}

Raza, Clase y Desigualdad de Ingresos en Brasil: Un Análisis de Trayectoria Social

El artículo trata de la relación entre raza, clase e ingresos en Brasil, con el objetivo principal de investigar los determinantes de las desigualdades raciales en el mercado de trabajo del país. Al hacer uso de modelos de ecuaciones estructurales, analizamos el proceso de establecimiento de diferenciales de renta entre blancos y negros, desde su origen social hasta la definición de salarios, a través de la escolarización y la asignación ocupacional. El análisis, con base en los datos de la Encuesta Nacional por Muestra de Domicilios aplicada en 2014 permite comparar los efectos directos, indirectos y totales de la raza y el origen social sobre la renta de trabajo. Los resultados muestran que, a pesar de que los efectos totales por el origen social sean mayores que los efectos raciales, los primeros no pueden explicar la mayoría de las desventajas sufridas por los negros actualmente en Brasil que ocurren principalmente de modo indirecto - a través de la educación y de la ocupación. Así, el artículo trae evidencias nuevas, actualizadas y más detalladas para un debate de larga duración.

Palabras clave: desigualdad de renta; raza; clase; estratificación social; trayectorias sociales 